\title{
ABOUT THE TRAGEDY OF MIRZA ULUGBEK
}

\author{
Ruzikul Boynazarovich Mustafokulov
}

Assistant Professor, Ph.D,Termez State University, Uzbekistan

\section{ABSTRACT}

In this article, we are talking about the progressive and humane sovereign Mirza Ulugbek, who ruled Maveraunnahr for forty. About his work, which took place during the difficult periods of the formation and rule of the state of the Timurid dynasty. The article also tells about the opposing, enemy forces, the cunning cunning that took place in the ruler's palace, about the struggle between darkness and occurrence, negative phenomena and consequences that led to the death of the main character Ulugbek. The article also reveals the positive aspects of the ruler as a humanist, scientist and patron of science.

KEYWORDS:- Ulugbek, tragedy, theme, enlightenment, internals, great humanist, struggle for the state, tragic outcome, values.

\section{INTRODUCTION}

One of the most important issues is to develop the knowledge, skills and abilities of young students, to teach them to work creatively, to think independently, to direct them to the profession, to expand their scientific outlook, to teach them to think logically.[1]

The fact is that this era of globalization poses a serious threat to the future of humanity, as well as the obstacles that the everyday life, as well as the growing generation ofyoung people, choose to make the right way in the face of the influx of ideas[2].

Ulugbek (1394 - 1449) during his forty years of reign was the most progressive and relatively humane sovereign among the Timurid generations. He not only limited himself to a benevolent attitude towards the development of various fields of science, but also made this science himself, becoming one of the great astronomers in world science. His "New Astronomical Tables", defining the positions of the stars, gained worldwide fame. Therefore, he remained in the history of mankind not as a successor to the deeds of Timur, the conqueror of the world, primarily as a patron of science and enlightenment and as a great scientist astronomer. In such a contradictory social position of Ulugbek: on the one hand, the ruler of the country, on the other hand, a prominent figure in science and patron of education, all the insoluble contradictions of life are tied at one point. At this point is the personality of Ulugbek.

\section{Analaytical RESUlts \& DISCUSSIONS}

In the Middle Ages of the East, religion, being a serious social force, spread in all spheres of society. This privilege strengthened the rights of religion and put a powerful weapon in its hands for the struggle against its worst eternal enemy the gravedigger - against science and enlightenment and their materialistically correct 
CURRENT RESEARCH JOURNAL OF PEDAGOGICS 2(11): 87-95, November

2021 DOI: https://doi.org/10.37547/pedagogics-crjp-02-11-18

ISSN 2767-3278

(C)2021 Master Journals

\section{Crossref do) 8 Google}

Accepted 25th November, 2021 \& Published 30 ${ }^{\text {th }}$ November, 2021

conclusions about life and the objects of the world. For these conclusions, the scientific conclusions of Soviet science, in particular, the great discoveries of Ulugbek in the field of astronomy were the strongest blows of the fanatical scholastic teaching of religion about the origin of the world. This situation, created in the life of the region, under the conditions of medieval feudalism, greatly exacerbated social contradictions.

The clergy, greatly worried about the discoveries of Ulugbek, in order to prolong the life of their religious convictions, opposed all their supporters to the scientist and the king. All representatives of religion sharpened their teeth on Ulugbek. For, according to the spirit of the times, Ulugbek, as a king, was obliged to take under his wing all the rulers and adherents of religion and pursue their line in life. However, the tsar's strong love for secular science, willingly or unwillingly, restored great power against him. Only these contradictions of the era could become a source of serious danger to the life of Ulugbek. In addition, the desire for power grew among the Timurids, as a result, they waged civil wars everywhere, devastating the economy and culture of the region.

Here, of course, the interests of the clergy and those frantically fighting for the throne could converge, in whose person a social force appears, preparing the ground for the physical destruction of Ulugbek. Another fact that complicates Ulugbek's activities, testifying to the compelling forces that opposed the scientist, is Abdulatif's participation in intrigues organized against his father. The careerism of Abdulatif, who fiercely fought for the seizure of the throne of his father, led to the commission of a brutal act. He himself, sending Ulugbek to Mecca, after him organizes a secret conspiracy with the reactionary clergy and dissatisfied Shah elements to physically destroy his father. Abdulatif went down in history as a parricide.
After him, he executed his brother Abdulaziz and emirs close to Ulugbek. Among them are Muhammad Tarkhan, Sulton Junaid, Ismail Sufi Tarkhan, Sultan Shah and many others.

The intentions, thoughts, envy of the representatives of the opposing forces are revealed earlier than the experiences of Ulugbek. They, organizing a conspiracy with the help of hostile forces, using their cunning and cunning, are preparing an unexpected blow to the king. Contradictions, all becoming more complicated, turn into a tangled knot. This knot is unraveled by the death of the protagonist Ulugbek. The contradictions that existed before the death of the protagonist, built on the basis of the models "life and duty", "personality and society", rise to insoluble complexity and attract the characters of the tragic current to their terrible depth.

Great scholarship, educational activities contradict the dominant principles of the era: the main character tries to put the tsar's activities at the service of science, but this noble goal leads him to tragedy and death. Thus, in the denouement over the scientist Ulugbek, the main dominant social force, the reactionary power of power, wins.

As a result of the advocates of science and enlightenment against the reactionary spirit of the times, its bulls and morals that keep people in the dark, a field of irreconcilable struggle emerged. The daughter of the representative of the clergy Said Abid is kidnapped by Ulugbek's disciple Gafar. The father demands the punishment of the "thief". However, Ulugbek, as a great humanist, instead of punishing, promises to help young people in love. This played into the hands of Said Abid. He accepted the scholar's humane decision as a humiliation of his honor and desecration of the foundations of the Koran. And between the king and the confessor Said, a conflict has long matured, as evidenced by the words of Said Abid himself: 
CURRENT RESEARCH JOURNAL OF PEDAGOGICS 2(11): 87-95, November

2021 DOI: https://doi.org/10.37547/pedagogics-crjp-02-11-18

ISSN 2767-3278

(C)2021 Master Journals

\section{Crossref doi) 81 Google}

Accepted 25th November, 2021 \& Published 30 ${ }^{\text {th }}$ November, 2021

Тоат, ибодат,

Бединлардан жирканмоқ, бутунлай нафрат,

Фоний дунё лаззатидан хазар, алхазар,

Дин йўлида шахид бўлиб саодат топмоқ. (1)

(Prayers, humility, Disgust for the unfaithful, full of hatred, Abominable sweetness of earthly life, alas, Die for religion and acquire happiness). Ulugbek answers Said with the dignity of a Shah severely and stubbornly with irony:

Аммо, билинг, анойи Сайид,

Мен, атайлаб, бажармайман шу орзунгизни.

Энди сизга жавоб, кетинг! 1

(However, you should know, naive Said. I deliberately will not let this dream of yours come true, now you are free, go). According to Ulugbek's convictions, a person, regardless of his origin, remains a person, there is no difference between people. All of them are people, with their cares, destinies similar to each other. And he looks at people like Said Abid with hatred, characterizes them with harsh words:

Ух,... Бу манфур бойўғлилар, нур душманлари,

Умримизга эгов бўлган хароми қуртлар...

Бу кишининг сайидлигини аясам... Аттанг... 3

(Ah ... These vile owls, enemies of the world, Vile worms of our life ... I still regretted that he was a seid ... Well, annoyance ...)

The whole tragedy is imbued with a sense of justice, characteristic of Ulugbek, combined with regret and sadness, which are born of complex contradictions and relationships between the characters. Ulugbek fights not only against the

1.Мақсуд Шайхзода “Мирза Улугбек”. Тошкент

"Ўқитувчи - 1994,34 ст

2.Тамже Стр.34

3.Там же. Стр.34

4.Там же. Стр. 110 forces openly attacking him, but also bothers about a collision that arose on the basis of the complexity of his personality as a king and a scientist. His words - "I made power a servant of enlightenment" - did not come true: the crown and science, religion and enlightenment are like fire and water. They cannot be reconciled. The efforts of the scientist were fruitless. That is why Ulugbek is seized by bitterness, endless suffering and regret. He does not understand, wonders why, after all, the good, realized by him, not only does not give its fruits, but generates evil:

Кўп ғалати замонада яшар эканман,

Қалбимдаги хароратни инсонга бериб,

Звазига олмокдаман совуқ ғаразлар.

Мен отамга, жаннатмакон Шохрух Мирзога

Қамарбаста ўғил бўлдим қирқ йил муттасил.

Аммо, шуни ўғиллардан кўрмадим, хайқот.

Абдулазиз фикри заиф, жисми ногирон

Абдулатиф - жисман тетик, хулқи хатарли.

Бу-ку майли! Оналарнинг икром-иззатин

Умр бўйи талқин этдим ахли ватанга.

Ўз онамга эхтиромим эвазига мен

Не эшитдим? Зуғум билан таъна, аразлар... (4).

(I live in a very strange world; giving the warmth of my soul to people, I get cold envy in return, I served my father, heavenly Shahrukh Mirza for forty years as an exemplary son. However, I have not seen this in my children, alas. Abdulaziz is weak and weak, Abdulatif is strong, but his behavior is dangerous. Okay that. He called all his life the people of the country to pay tribute to their mother, But for respect for my mother. What did you listen to? - bitterness, reproaches, insults ...).

The blow inflicted on Ulugbek by the reactionary clergy, who had been sharpening their teeth on 
CURRENT RESEARCH JOURNAL OF PEDAGOGICS 2(11): 87-95, November

2021 DOI: https://doi.org/10.37547/pedagogics-crjp-02-11-18

ISSN 2767-3278

(C)2021 Master Journals

\section{Crossref doi) 81 Google}

Accepted 25th November, 2021 \& Published 30 ${ }^{\text {th }}$ November, 2021

him for a long time, intrigues organized by the unlucky son Abdulatif and the thoughtless mother Gavharshodbegim together with representatives of religion, the contradictions between the duty of the king and the duty of a scientist, as a result of terrible grief, terrible events that shook the soul - all this taken together constitutes a single knot of tragedy. According to the laws of the tragic idea, the tragic spirit of the conflict is gradually increasing. Here, the tragic fate of the hero is subjected to yet another complication based on family relations: Ulugbek loves the gardener's daughter. However, this love once again shows the human qualities of Ulugbek's character. His suffering, sadness and cry of the soul deepen the sources of life conflict and sound like an expression of hatred for the inequality in love, enshrined in the mores of the Middle Ages:

Ха, Феруза, мен буларни яхши сезаман,

Балки сени хурлайдилар орқаворатдан.

Боғбон қизи, паст тобака, фуқаро дерлар.

Зотан, сира тушунмаслар, бечора кўрлар

Олтин кукдан тушмас, ернинг тагидан чикар.

Сен бек қизи эмассанки, бўлолсанг бека.

Сен хон қизи эмассанки, бўлсанг хоника.

Султон ва шох насабидан эмасдир аслинг,

Хўжалардан, сайидлардан эмасдир наслинг.

Аммо сенинг шажарангда бир устунлик бор:

Онанг мехнат, отанг эса - заковат бўлмиш... 5

(Yes, Feruza, I feel all this well, Maybe they will humiliate you secretly, Saying, the daughter of a gardener, a low family, from the simple. For these wretched, blind people will never understand that gold is hidden in the depths of the earth, not in heaven You are not a daughter of a master to become a mistress, You are not a daughter of a khan to become a mistress. You are not from the generation of kings and sultans, Your family tree is not connected either with the Khoja or the Seits, However, there is an advantage in your family tree. Your mother is labor, your father is the ability to know ...).

The realistic content embodied in a romantic play is gradually deepened by the ideas of love for a beautiful, moral person, and is perceived as a wonderful result of a skillfully created tragic collision. The tragedy is built here not on personal, but on social and public interests. This basis of the tragedy is shown by the resentment, reproaches of Ulugbek, said by him in a conversation with his own mother Gavharshodbegim. At the same time, in every word of the protagonist, monologues, experiences, the poison of heavy grief, an approaching terrible tragedy, is more and more clearly felt.

Ха, чиндан хам, сизни яхши билмас эканман.

Оналикнинг хақи, аммо, бор бўйнимизда.

Бироқ, хурмат-кўр-кўрона итоат эмас.

Таажжубки, сизда шунча заковат бору;

Бошқа хамма хотинларни пастга урасиз,

Ахир сиз хам аёлларнинг вакиласи-ку.

... Абдулатиф, Ало билан Бобир - уч қардош

Бир-бирига лашкар тортиб савашди ёвуз.

Абгор бўлди қанча шахар, инсон, хазина.

Учови хам набирангиз, дастпарвардангиз.

Бирин кўзлаб, бирин қоқиб, бирин эркалаб,

Нуқул жанжал чиқардингиз ўрталарида.

Йўқ бу ахлоқ, бу тарбия, бу одат-удум

Самарқандда ўрнашига йўл қуёлмайман.

ўғлингизман ва ўпаман қўлларингизни,

Тиз чўкмакка омодаман хузурингизда. 
CURRENT RESEARCH JOURNAL OF PEDAGOGICS 2(11): 87-95, November

2021 DOI: https://doi.org/10.37547/pedagogics-crjp-02-11-18

ISSN 2767-3278

(C)2021 Master Journals

\section{Crossref doi) 81 Google}

Accepted 25th November, 2021 \& Published 30 ${ }^{\text {th }}$ November, 2021

... Сиз-малика, аммо билинг, эмас хокима.

Жавоб аччиқ, лекин очиқ, айни хақиқат.

Эх, сизсиз хам бадхохларим кам эмас эди. ${ }^{6}$

(Yes, indeed, it turns out, I did not know you, But respect is not blind obedience. The duty of a son, however, is on our neck. Surprisingly, having so much intelligence, You humiliate all other women, After all, you yourself are a woman ... Three relatives "Abdulatif, Alo and Babur brutally beat each other on the battlefield. How many cities, people, wealth have been trampled. Three are also your grandchildren, pupils of your hands. Caressing one, teasing the other, persuading the third, Constantly kindling discord between them. No, I will not allow so that this behavior, this upbringing, and customs and mores take root in Samarkand. I am your son, I kiss your hands. And I will kneel before you ... But you are the wife of the (former) king, not a ruler, The answer is bitter, but open and fair. And without you I had quite a few enemies).

Here Ulugbek criticizes the khans and bays, the customs and orders that reign in the life of the people. Dealing blows to the age-old vices of society, protects the interests and rights of the poor. At the same time, he feels the pressure of the hopelessness of the situation and realizes that there is no escape from the tragedy. The son and mother of Ulugbek, who constantly fought for the king's crown, spreading various slander, organizing intrigues, using their cunning, contributed to the acceleration of Ulugbek's tragedy.

This is how the conflict between the humane father and the power-loving son reached its climax. This is how viciously, with reproach, this impudent, dishonorable Abdulatif speaks to his father:
Бузрукворим, наслингизни нобуд қиласиз.

Ахир бемор, ақли косир, Абдулазизми

Улугбекнинг салтанатин давом эттиргай?

Тахт ўтади бегоналар қўлига, султон! (7).

(Father, you will ruin your pet. Abdulaziz, who is not insane and sick, will sit on the throne of Ulugbek. The throne will pass into the wrong hands, ruler).

Ulugbek:

Тахт, Темурий хонадонин бобо мероси.

Чиқиб қолар ақли расо бирон темурий.

Не қийлайки, Улугбекнинг зурриётига

Бу тахт насиб эмас экан. Ва яна билки,

Менинг хали ўлмоқликка иштиёқим йўқ. 8

(The throne is the legacy of Timur for his grandchildren. May some clever Timurid come out among them. Unfortunately, there were no such among Ulugbek's children. And you should know, I have not yet had a desire to die).

Abdulatif:

Бу иллатдан менинг халок бўлмоғим афзал.

(It is better for me to die than to endure such humiliation.) In the final of the tragedy's actions, Ulugbek's life ends and the power leaves him. However, the main character understands that Ulugbek the scientist will live in the hearts of generations of all ages as long as mankind is on earth:

... Замон ўтар, вахшат битар, ёмонлик кетар,

Ўзгаради дунёмизда динлар, миллатлар,

Ўзгаради миллатларда тиллар, одатлар,

Аммо фаннинг шавкатига чўкмайди ғубор. (9).

8.Там же. Стр. 148.

9.Там же. Стр. 174. 
CURRENT RESEARCH JOURNAL OF PEDAGOGICS 2(11): 87-95, November

2021 DOI: https://doi.org/10.37547/pedagogics-crjp-02-11-18

ISSN 2767-3278

(C)2021 Master Journals

\section{Crossref doi) 81 Google}

Accepted 25th November, 2021 \& Published 30 ${ }^{\text {th }}$ November, 2021

(Time will pass, there will be no cruelty, evil will disappear, Faith and nations will change in our world, Languages and customs will change in them, But even then the honor of science will not fall).

The spiritual tragedy of King Ulugbek reaches its climax. Standing at the grave of his grandfather, the conqueror of the world, he addresses him. Here the author masterfully conveys the state of the hero, who fell into despair because of the injustices of the world. Ulugbek reproaches himself for not being able to justify Timur's trust.

Шу-қирқ йиллик андишага аламли якун.

Кетиб қолди замондан диёнат, ростлик.

Мудхит бир жар ёқасида турмиш мамлакат.

Зулматли тун қўнаётир юртнинг уфқига.

Бобо Темур, омонатинг сақлаёлмадик.

Авлодларинг чиқиб қоди ғоят ноқобил.

Мен у ёвни кўкрагимда парвариш этдим.

ўғил дедим, нуқсонларин ундан бекитдим.

Тарбияда талабчанлик шартин унутдим.

Томиримда гарчи юрар Темурнинг қони,

Аммо менда Темурбекнинг шадодлиги йўқ

Мен хеч қандай тахликадан хайиқмайман; йўқ,

Мен ўлимни хоким эмас қўл деб санайман.

(The lot that we got is not easy

A shadow falls on the breadth of your land.

For this long forty years,

My formidable grandfather, Timur, we could not

Preserving your country is your legacy.

Thy flesh was getting smaller, your breed ...

I'm a son on my chest in the old days

He grew up and did not live, there is no tea in him,
The trouble with the fathers is not that they

The vices of sons do not notice ...

Tell me, Timur, I'm weak in spirit, in me

Only your blood, but not your cruelty ...

Please, my great grandfather, give some reason:

Is the essence of the kingdom mercy or violence? (ten). (tr. by N. Grebnev)

Ulugbek does not come to the grave of the "great grandfather" to ask for the help of his spirit, no. At the grave he confesses his mistakes and the fact that he is ingloriously ending his reign. The author, drawing the romantic image of Timur, reveals his spiritual world, morals, the method of struggle for the state, the methods of conquering the world, that all his power was based on the power of a mercilessly punishing sword in the strong hand of the ruler, which, according to Timur, is close to the two kings in this world, and if he had to live for another 10-15 years, there would be no state on earth unconquered by his sword.

Шахрисабзлик Темурбекнинг вахимасидан

Қалтирарди етти иқлим тоғу тошлари.

Самарқандда бир йўталсам, бунинг зарбидан

Ёриларди халифайи Богдоднинг ўти.

Исфахонда зилзиладек қимирларди ер,

Бир наърамдан келар эди, шохларнинг тожи,

Пойтахтимга оқар эди дунёнинг божи...

Улуғбекни мен кўргидек бўламан хозир.

Ўғлим сенинг иродангни еб қўйди китоб.

Инсоният тарихининг қалами шамшир,

Унинг учи қонлик бўлса ўхшайди тасвир. 11

(I grew together with the saddle, I got used to the sword,

11.Стр. 175 
CURRENT RESEARCH JOURNAL OF PEDAGOGICS 2(11): 87-95, November

2021 DOI: https://doi.org/10.37547/pedagogics-crjp-02-11-18

ISSN 2767-3278

(C)2021 Master Journals

Crossref doi) 81 Google

Accepted 25th November, 2021 \& Published 30 ${ }^{\text {th }}$ November, 2021

I bore power and sorrow to all the lands of the world.

I knew that the world is small for two lords,

Now it is spacious for a hundred kings!

And you, my darling, my poor grandson,

Science has killed your formidable temper.

Letting go of earthly rati.

You began to dispose of the army of the stars!

The world does not move by the power of love -

With a steel sword in the right hand of a warrior,

When; a historian's feather in blood,

More beautiful than the history of the page ... (translated by N. Grebnev)

In fact, Ulugbek never spoke with his grandfather. Here the writer, using the conventions of artistic creativity, conveys the inner thoughts of the protagonist, the truth that he reveals at the end of his reign. The hero, now returning to reality, realizes that all the paths that face him do not lead him to happiness, because his character and activity are incompatible with the laws of the then social order, the tragic outcome of his fate has already been prepared. But feeling all this, Ulugbek does not give in to pessimistic feelings, for:

Тирикларнинг рўйхатидан, ким билар, бу гал.

Қай бирини ўчираркан котиби азал.

Ким билади, балки навбат менга етгандир.

Чунки умрим ози қолиб, кўпи кетгандир.

йўқ,-йўқ, султон ўлса хамки, донишманд яшар.

Олимларга мангу хаёт-тарихи башар. 12

(I became old too, my turn is coming

Move to this settlement.

12. Стр. 177
The world will forget me, the king,

As soon as my earthly age is lived,

But what I have discovered, what I have spoken,

Perhaps it will remain in the minds of people

And the astrologers will remember me! ...) (trans. N. Grebnev)

Ulugbek looms before the eyes of readers and viewers as a thousand-year plane tree, striving for heaven, relying on its native land with its powerful roots. Positive and negative images people of typical characters, providing immortality to the main character of the tragedy, shine around him like stars.

Feruza is one of the most successful images of the work. The daughter of a simple gardener, who became Ulugbek's beloved wife, was drawn with great sympathy from the author and turned into a symbol of love and fidelity. Her fate is also tragic, although in the finale she does not die. However, love, duty and honor were trampled down, the person closest to her was killed.

\section{Conclusion}

All this leads her to bitter suffering, intensifies, spiritual tragedy. This image reveals the bright positive traits of the protagonist, serves as the key to understanding the world of intrigue and slander, aimed at weakening the energy and spirit of Ulugbek. As a like-minded person of the protagonist, she also experiences the blows that were inflicted on the king and scientist Ulugbek. Therefore, you can include Feruza in a number of tragic images of the work.

Another image that has enriched Ulugbek's character with the qualities of humanity is Piri Zitsdani. The playwright, relying on him, endows the character of the protagonist with the features of a just ruler. This image conveys the confusion and complexity of the spirit of the era and Ulugbek, and the fate of those who rebelled 
CURRENT RESEARCH JOURNAL OF PEDAGOGICS 2(11): 87-95, November

2021 DOI: https://doi.org/10.37547/pedagogics-crjp-02-11-18

ISSN 2767-3278

(C)2021 Master Journals

\section{Crossref doi) 81 Google}

Accepted 25th November, 2021 \& Published 30 ${ }^{\text {th }}$ November, 2021

against the oppression of the history of the reign of Timurids.

A fighter for justice and freedom - Piri Zindani is also tormented in bewilderment. His tragic soul is tormented by thoughts: kings, khans and emirs, religious fathers oppress the people and are at enmity with each other. But at the same time, the death of a just, humane, great man, a brilliant representative of science Ulugbek, brings endless suffering to his soul. Here we recall the controversy started in connection with the question of the vital truth of the time of the war, which is directly related to the image of Abdulatif. In the controversy, the following position was promoted: an example of a tragedy should induce, in addition to anger and hatred for one side or another of the person's actions depicted in the work, the pity and compassion of readers and spectators. A work deprived of these properties will not have a full-fledged aesthetic essence and value. For in the presence of these qualities lies the strength of the aesthetic, moral impact of the work, i.e. catharsis - power cleansing the soul from suffering and vices.

Life's contradictions and difficulties take on aesthetic significance if they can awaken feelings of fear, pity, and empathy. Based on this, it can be argued that the very complexity of life has an aesthetic essence. In this sense, in the play "Mirza Ulugbek", Abdulatif's actions, on the one hand, evoke hatred, anger and fear, on the other, pity and compassion. His cruelty, his desire to seize the king's crown with the help of such vile people, led to a bloody massacre over Ulugbek the great son of the people of the Middle Ages. The pity, sympathy, grief, fear and tears generated by these events determined the aesthetic value, a sense of pride in the protagonist, purifying the spirit of many works of different genres written on this topic.

\section{ReFERENCES}

1. Dilorom Sharifovna Yakibova. The Importance of Shaping Students' Creativity in Elementary School Technology Classes. International Journal of Discoveries and Innovations in Applied Sciences. ISSN 2792-3983 (online), Published under Volume: 1 Issue: 6 in November-2021. http://openaccessjournals.eu/index.php/ij dias/article/view/661

2. Sharif, Y., \&Dilorom, Y. (2019). Integration in primary education as factor mentality. International Journal of Engineering and Advanced Technology, 9(1), 4854-4856.

3. Мақsud Shaikhzoda. Mirza Ulugbek. Toshkent: Kituvchi, 1994, 34 st

4. Ibid. Page 34

5. Ibid. Page 34

6. Ibid. Page 110

7. Ibid. Page 72

8. Ibid. Page 100.

9. Ibid. Page 148

10. Ibid. Page 148.

11. Ibid. Page 174.

12. Ibid. Page 175.

13. Ibid. Page 177.

14. Yakibova, D. (2021). Methods for enhancing the creative thinking of primary schoolchildren. Heraldpedagogiki. Nauka i praktyka, 1(1).

15. Dilorom Sharifovna Yakibova. Ways to develop students' creative thinking skills in primary school technology lessons (based on pedagogical technologies). Asian Journal of Multidimensional Research (AJMR). DOI: 10.5958/22784853.2021.00251.2 
CURRENT RESEARCH JOURNAL OF PEDAGOGICS 2(11): 87-95, November

2021 DOI: https://doi.org/10.37547/pedagogics-crjp-02-11-18

ISSN 2767-3278

(C)2021 Master Journals

Crossref dof 81 Google

Accepted 25th November, 2021 \& Published 30th November, 2021

16. Yakibova Dilorom Sharifovna, Yakibov Baxtiyor. Labor education in the legacy of thinkers (on the example of technology lessons. ICIPPS JUNE 2020. DOI. 10.17605/OSF.IO/ARFSB 